\section{Introduction: Real World Learning- Recalibrating the Higher Education Response Towards Application to Lifelong Learning and Diverse Career Paths}

\author{
Dawn A. Morley and Md Golam Jamil
}

\section{Reviewing Current Higher Education Provision for Employability}

Over the last 20 years, higher education has been increasingly audited for its relevance to the student population-whether this is for the quality of its provision, the ability to place students in employment with meaningful 'learning gain', or its response to the student voice. Historically, there has been a split between higher education curricula, employment sectors and students' career objectives (Finch, Falkenberg, McLaren, Rondeau, \& O’Reilly, 2018; Miles, 2017). Many profession-focused academic

D. A. Morley $(\bowtie)$

School of Sport, Health and Social Sciences, Solent University,

Southampton, UK

M. G. Jamil

Bristol Institute for Learning and Teaching, University of Bristol, Bristol, UK

D. A. Morley, M. G. Jamil (eds.), Applied Pedagogies for Higher Education, https://doi.org/10.1007/978-3-030-46951-1_1 
programmes often fail to stay relevant with the rapid transformation of global labour market and the demands of new skill sets from employees (Trilling \& Fadel, 2009). This creates the risk of outdated academic practice, leading to potential talent gaps in industries, indicated by the wide selection of degree apprenticeship programmes that have been developed in response (Morley, 2017).

Measurement of student outcomes, the longer tradition of grafting employability skills into courses (Atkins, 2009; Bridgstock, 2009; Mason, Williams, \& Cranmer, 2009) or adding placements into the student experience highlights the increasing recognition that students' graduation is the first step, and not the destination, in their learning and working trajectories. To address the shortfall of employability attributes among university students, many universities have begun both academic and non-academic interventions, such as job-focused academic programme design and faculty development with enhanced industry exposures (Nguyen, Tran, \& Le, 2019). However, most of these initiatives have failed to demonstrate positive learning outcomes in terms of preparing job-ready graduates (Woodside, 2018). There is a criticism that vocationally oriented curricula are 'dumbing down', causing the 'loss of critical mission' (Turner, 2011). Traditional learning and teaching practices, which are generally academic skills-oriented and content-based, are not always appropriate to prepare students as global citizens and job-ready graduates (Woodside, 2018). These two contrasting and challenging areas in higher education curricula demand a proper balance between academic rigour and work-related competencies in teaching and learning. On the one hand, university students need academic rigour in their learning to expand and renew strategic capabilities. On the other, they require instituting real-life connections and competencies transferable to future profession and work.

In contemporary economic and educational policies, graduate employability has emerged as a defining factor for the overall enhancement of human capital and economy (Tomlinson, 2017). The European Commission in its Education and Training Monitor 2014 report calls for enhancing graduate employability skills that can benefit the society and labour market (European Commission, 2014). Australian higher education has adopted a 'demand driven system' investing a significant amount of funding for universities to respond to the needs of efficient workforce 
(Bridgstock \& Cunningham, 2016). In UK higher education, an emphasis has been placed on the application of learning to academic and professional areas. The National Student Survey (NSS), a key indicator to measure student satisfaction and teaching quality in UK universities, contains questions such as 'my course has provided me with opportunities to apply what I have learnt' to gauge the extent of real world rigour and academic-industry links in the academic programmes (Office for Students, 2019).

UK higher education institutions have responded proactively to improve their performance in the annual NSS particularly as results feed into the core metrics of the university's Teaching Excellence Framework (TEF) ratings. Most notably, the work on learning gain and the TEF in the UK has more recently unravelled as too difficult or statistically flawed (Kernohan, 2018; Shah, 2018) to continue in its present form, bringing into question the ability to measure a correlation between learning and postgraduation employment. Added to the question of the viability of employment measures in higher education, the new Graduate Outcomes Survey, the largest social survey outside of the ten-year census, relies on students to complete the survey 15 months after graduation. Already there are concerns that the survey will attract response rates up to $20 \%$ below its predecessor, the Destination of Leavers from Higher Education (DLHE) Survey (Grey, 2018).

It seems that time is of the essence to revisit the appropriateness of modern curriculum to deliver student learning that has relevance after graduation. The Inaugural Global Learner's survey (Pearson, 2019), of 11,000 learners between 16 and 70 years old in 19 countries, acknowledges that the 40-year career has now gone and needs to be replaced by educating for lifelong learning and diverse career paths.

\section{Using Theory to Elicit a Changing Pedagogy for Employability and Lifelong Learning}

Knud Illeris, publishing in the 1990s, foresaw an approaching juxtaposition between the way students learnt and the way they were taught that insufficiently prepared them for the changing postgraduate landscape. 
Changes of late modernity are fundamentally changing the conditions of learning, and if politicians, administrators and educators are to cope adequately with this, as educational researchers we must be able to develop adequate theories matching the problems experienced at all levels. (Illeris, 2003, p. 404)

He argues (Illeris, 2003) that learning cannot be straightjacketed into a curriculum but requires a broader foundation to be responsive to the wider goals of learning. Billett (2010) supports this view that higher education's emphasis on educational provision privileges more traditional learning. By doing so, transformative opportunities for learning, such as those found outside of the curriculum and more creatively added to the curriculum, may be overlooked.

The question arises as to whether higher education pedagogy risks being out of sync with students' immediate and postgraduate needs. Higher education continues to make a distinction between the students' own personal cognitive learning processes and socio constructivist learning where students' learning is situated from their own experience and that of others (Wenger, 1998). Illeris (2003) argues that assimilated learning, which adds to previous knowledge and experience, is common but realises greater learning impact occurs when the process is disrupted, and the student must struggle to accommodate new learning into their existing schema.

Heath and Heath (2017) advocate transforming the flat landscape of experience by punctuating it with memorable events that have impact for the individual. This is not to be confused with 'being entertained', and both academics and students often comment on the acceleration of skills and development that occur during student placement opportunities (Morley et al., 2017). There is no coincidence that the type of learning that students experience in the world of work is fundamentally different from that experienced at university - theoretical knowledge is applied and challenged, expectations on standards and performance are constant and students work up against experts who can be questioned and, in their turn, give feedback in real time. Overall, learning is much more organic, exposed and dependent on students' own individual effect. Much can be learnt from the area of work-based learning which Lester and Costley (2010) argue has a particular pedagogy to support its learners. 
An innovative approach to learning 'break(s) the script' (Heath \& Heath, 2017) that can be memorable both during and after the event. By making a personal connection with students, in either their present or their future selves, personalises their learning, for example, resonance with an outside presenter or greater accessibility to learning materials sympathetic to students' own learning preferences, increases students' understanding and ability to question. The recognised barrier of the gulf between the learning at university and its application, 'the theory-practice gap', can start to be addressed by stimulating students' curiosity and giving them the confidence to ask questions. Arguably, a curriculum that encourages the use of innovative pedagogies, such as inquiry and peerbased learning, may provide a stronger lead to social models of learning and the development of both individual and team learning skills. A piquancy is added by a third factor; stakes are heightened by learning strategies that aim to make the learning event crucial through, for example, links to assessments or the opportunity for public scrutiny such as student-led journals or retail initiatives.

Carefully considered curriculum design that addresses the impact of learning through novelty, application and personal development is arguably more attuned to students' current needs for higher education and later employment. The challenge is to move real world learning into a robust, research-informed position so its implementation does not occur by accident, but it is considered against the more traditional taxonomies of learning and established pedagogic theory. University structures, more reflexive to a process-led curriculum with an emphasis on personalised and appropriate support structures, may also do better to resituate learning in higher education institutions to a real world ethos.

Theorists, influential to practice pedagogy, look closely as to how learning is situated and how the environment can be altered to promote higher level learning. Fuller and Unwin's (2003) research of apprenticeships identified a 'restrictive-expansive continuum' that classified the type of learning environment presented in the workplace. Crucially, expansive learning encouraged a supportive environment for students to learn higher level skills such as dialogue, problem solving and reflexive forms of expertise. What could be isolated as soft skills, important for employability, are highly valued and explicitly incorporated within the learning. 
Ellstrom (2011) also makes a similar distinction between an enabling and constraining learning environment whereby the structures in the practice setting impact on how easily a student can move between adaptive (skills acquisition) and developmental (professional critique) learning. A constraining working environment can prioritise adaptive learning, or be detrimental to the development of both, with students displaying the attributes of acquiescence. Although the prioritisation of adaptive or developmental learning may naturally and appropriately occur during their learning, students need encouragement to be able to question what and how they are being taught. The interdependency between knowledge and practice where one promotes the other (Schön, 1983) advances this learning further.

The strong emphasis on the learning application and graduate employability suggest modernising the existing educational objectives and pedagogic approaches in higher education curricula. Applied Pedagogies for Higher Education. Real World Learning and Innovation Across the Curriculum responds to this call and provides an evidence-driven discussion linked to different academic disciplines. The curricular approaches are centred on real world learning pedagogy which demonstrates strengths to improve deep learning and graduate employability skills.

\section{The Emerging Power of Real World Learning}

Real world learning is a developing educational concept in the higher education literature. The approach contains the ethos of deep, experiential, personalised and applied learning experiences (Boss, 2015; Rau, Griffith, \& Dieguez, 2019; Sharma, Charity, Robson, \& Lillystone, 2018). There are several pedagogic proposals, reaching from academic programme to sector levels, suggesting curricular tactics that can facilitate real world learning in higher education and, at the same time, minimise theory-practice gaps. Examples of recommendation include universityindustry partnership (Finch et al., 2018), civic engagement (Jacoby, 2009), collaboration and reflection (Herrington, Reeves, \& Oliver, 2010; Schön, 1983), and using authentic content and assessment in teaching and learning (Remington-Doucette et al., 2013). 
Real world learning has not yet emerged as a distinct pedagogic model or approach, but in many teaching and learning discourses, the expression is used to refer to students' positive learning experiences and gains. For example, the term 'real world learning' has been used to describe long-term, experiential and applied learning (Rau et al., 2019; Sharma et al., 2018). It has also been portrayed as interdisciplinary and competence-based learning which can equip students with applied knowledge and skills, such as problem-solving, decision-making and planning to handle real world challenges as well as accomplish real world tasks (Holley, 2009; Moore, 2011).

The aim of this book is to address the shortfalls that currently exist in developing graduates' work readiness. Currently real world learning lacks definitional clarity and evidence-based descriptions, particularly when linked to higher education settings, and the intention is that this edited collection addresses these gaps. The chapters are centred on the case studies of 'real world learning' in different academic disciplines where students gain opportunities to focus on not only their present learning but how they can develop attributes and identities that equip them to progress following graduation. The book explores how higher education can be 'recalibrated' so the student experience becomes more orientated towards students' long-term development starting on day one of their higher education studies.

Up to this point, real world learning has established itself in primary and secondary education as a means for children to develop confidence and self-esteem in the compulsory education curriculum (Laur, 2013; Lucas \& Guy, 2013; Maxwell, Stobaugh, \& Tassell, 2015). Real world learning is now positioning itself in higher education academic programmes that are 'applied' where the need for an agile and authentic curriculum takes precedent (Marris, 2018).

It seems critical that real world learning, like other areas of academic development and pedagogy within higher education, is scrutinised and debated. To date, very little is written on real world learning in higher education apart from a focus on project work (Boss, 2015). The ethos and branding of real world learning need to be clear to both students, who are studying courses described under this banner, and academics who are designing real world curricula from a currently under-researched 
position. The book questions whether higher education curricula that link to work experience or applied examples are only accessing part of the potential of real world learning to help students learn in both their immediate and long-term development.

A qualitative research study complements the book chapters and is presented in the conclusion. Each chapter's authors formed their own focus group facilitated by the lead editor to explore real world learning through the methodology of concept mapping. The authors' individual maps and accompanying narrative are presented in each chapter. Concept mapping can portray the perceptions of the group, and the facilitating researcher, through interrogating the map that the participants provide, can enable the group to provide deeper and clearer links between concepts (Kinchin et al., 2018). For potentially complex and unexplored topics, such as real world learning in higher education, the method drew out ideas that participants used to contextualise the written narrative of the theme for their chapter.

The book has taken an approach aimed at addressing the areas found to be missing within the current literature. It critiques real world learning across the wide spectrum of both the curriculum and extracurricular activities. A cross-disciplinary approach draws on expertise from disciplines such as business, health, fashion, sport, media, sociology and geography. In this book, authors, and case study contributors, from 23 universities have shared their own expertise in 15 wider collaborative chapters on real world learning. While the book draws mainly on examples and case studies from modern UK universities, they are applicable to all vocational and professional degrees and will have resonance internationally. International evidence of real world learning in practice is drawn from the USA, Bangladesh and Australia.

The chapters are divided into three parts that reflect different aspects of this development.

Part I: 'Emerging Responses in Real World Learning' consists of five chapters, and both the authors and those academics that have provided case studies represent 12 universities from the UK, Ireland and Bangladesh. This part examines the broader application of real world learning across university ethos and policy. Chapter 2, 'Internal Knowledge Transfer: Professional Development Programmes and Embedding Real World 
Learning for Full-Time Undergraduates,' sets the scene, and Perrin, Hancock and Miller provide a discussion of the distinctive features of negotiated work-based learning frameworks that help capture and develop learning for part-time students who are professional practitioners. They demonstrate their established experience as to how approaches to teaching, learning and assessment in these frameworks can also be leveraged for programmes aimed at full-time undergraduate students wishing to engage with real world learning.

Chapter 3, 'The Role of Professional Networks in Supporting and Developing Real World Learning,' by Brindley and Sims, provides insight into how professional learning networks can be effectively implemented to encourage sharing of good practice and developed to support a real world learning context within higher education. Their case studies are drawn from practice team meetings and partnership learning agreements.

Chapter 4, 'Real World Learning Through Civic Engagement: Principles, Pedagogies and Practices,' argues for alternative transformational opportunities for students to experience real world learning through civic engagement. Mason O'Connor and McEwen present changing drivers to community-based learning from local to global, including newer imperatives of learning for sustainability, citizenship education and building resilience. It concludes by reflecting on the means by which radical real world learning through civic engagement can advance and thrive. This chapter is supported by case studies from Irish and UK universities in Chapter 5, which provide innovative evidence of civic engagement in action. Chapter 5, 'Working and Learning Through the Local Community: Four Case Studies from Higher Education That Promote Civic Engagement' (by Morley, Glesson, Mey, WarrenPerkinson, Bourne, King, Cooper and Reavey) illuminates different aspects of civic engagement with international students, through sport and health initiatives and as an extension of a teaching degree. Each case study demonstrates best practice recognised by their sustainability, growing reputation and ongoing positive impact on students' alternative real world learning experiences.

Chapter 6, 'Real World Learning and the Internationalisation of Higher Education: Approaches to Making Learning Real for Global Communities,' is authored by Jamil, Alam, Radclyffe-Thomas, Islam, 
Mollah and Rasel. Inquiry and application lie at the heart of real world learning, and the internationalisation of academic programmes are expected to equip learners with diverse learning styles and global citizenship skills. However, combining these two sets of educational objectives for pedagogic success is challenging, mainly because of learners' academic, social and cultural differences. The chapter addresses this problem theoretically and with the help of three real cases drawn from the UK and Bangladesh.

\section{Part II: 'Moving Learning into Real World Practice: Extending} Student Opportunities in Higher Education' examines pedagogy and strategy to enhance the impact of students' direct experience of practising in a real world setting. It consists of five chapters drawn from 13 universities in the UK and Australia. All the chapters provide examples of the theory and practice of implementing examples of real world learning pedagogies, or particular programme design, within authors' own disciplines that contribute significantly to the building of students' attributes. Part II reflects on the impact of students' direct experience of practising in a real world setting.

Morley, Marchbank, Steyger, Taylor, Diaz and Calleja, in Chapter 7, 'Designing and Supporting Extraordinary Work Experience,' recognise that real world learning experienced by students on placement is highly significant. The chapter explores emerging areas of practice pedagogy and how innovative design can bridge the theory-practice divide and support structures between university and work. Focus is placed on how these experiences can be accelerated from being part of courses to a pivotal event towards students' future development.

Chapter 8, 'Making Projects Real in a Higher Education Context,' by Hanney, draws on the work of the 'critical projects movement' framing the use of live projects as a mode of real world learning that generates encounters with industry professionals and provides real-value outputs for clients. The chapter explores the challenges that face educators who wish to foreground 'social learning' and engagement with communities of practice as a means of easing the transition for students from education to the world of work.

In Chapter 9, 'Real World Learning: Simulation and Gaming,' Lean, Moizer, Derham, Strachan and Bhuiyan present how simulations and 
games are being used across a variety of subject areas as a means to provide insight into real world situations within a classroom setting; they offer many of the benefits of real world learning but without some of the associated risks and costs. The nature of simulations and games is discussed with reference to a variety of examples in higher education. Their role in real world learning is evaluated with reference to the benefits and challenges of their use for teaching and learning in higher education.

Hann presents Chapter 10, 'Learning Enterprise and Entrepreneurship Through Real Business Projects,' which describes an experiential, real world approach to entrepreneurship education in HE known as 'Team Academy' and suggests a complementary conceptual grounding to the accepted curriculum using candidate entrepreneurship threshold concepts and pedagogical approaches identified from doctoral research. Four case studies are taken from the two oldest and largest UK Team Academy programmes to illustrate the approach and highlight the way in which an understanding of a selection of candidate entrepreneurship threshold concepts have been successfully developed in the students.

Hughes and Saieva, in Chapter 11, 'The Journey of Higher Degree Apprenticeships (HDAs), outline the history and rationale of the development of higher degree apprenticeships (HDAs) as well as explore how to embed the real-world ideologies to innovate curriculum. The necessity of strong support structures across the tripartite relationship to best meet the requirements of both apprentices and employers is emphasised. The chapter will also review the added value that HDAs bring, not only to the individual apprentices but to the organisations too, with the use of case studies and feedback from employers on the impact of the apprentice's work-based learning journey.

Part III: 'Future Higher Education Direction: Engaging Real World Learning Through Innovative Pedagogies' is drawn from nine universities in the UK, USA and Australia. It analyses the use of learning strategies, such as reflection and technology, on students' experience of real world learning.

Chapter 12, 'Making Inspiration Mainstream: Innovative Pedagogies for the Real World,' presents pedagogies that are flexible and studentcentred and focus on authentic, situated, real world tasks which are complex and non-linear. Buckley and Kukhareva argue for a higher education 
model that focuses on the 'beyondness' of learning and allows for alternative ways of seeing through the cross-pollination of disciplinary approaches, interactivity outside the subject group and flexibility in teaching spaces. The model makes explicit a learning community that exists beyond the immediate experience of the student with case studies that include a writing café, drama-based pedagogies and a virtual learning environment.

Trelfa, in writing Chapter 13, 'Getting to the Soul': Radical Facilitation of Real World Learning in Higher Education Programmes Through Reflective Practice,' foregrounds reflective practice as integral to real world learning in higher education. Concerning the development of professional 'artistry' of and for post-degree life, literature focusses on the nature and form of reflective activities to foster student scrutiny and therefore control of self and situation whilst engaged in real world learning. Yet, Trelfa's doctoral research suggests the only real 'learning' is correct performance to pass their course. Reflective practice, and real world learning, has 'lost its soul'. Drawing on Lefebvre's (1992/2004) concept of 'breaking-in' to understand this soul-less situation, Trelfa calls for it to be radically different: if real world learning is to live up to its name, then its reflective practice needs to be authentic.

Chapter 14 examines the context of 'real world learning and authentic assessment', and Archer, Morley and Souppez critique the value of building authentic assessment to reflect better a real world learning approach that prepares students more explicitly for employment after graduation. The two case studies within the chapter are drawn from the different disciplines of festival and event management, and yacht design; both aim to prepare students for their respective industries from the onset of their degree programmes. The case studies present how the use of well-managed pedagogic strategies, such as peer review and assessment, reflective practice and the use of formative feedback, can prepare students successfully for authentic and high-risk summative assessments.

The final two chapters of the book specifically focus on the role of technology in real world learning. Bolton and Emery, in Chapter 15, 'Using Educational Technology to Support Students' Real World Learning,' makes the case for students developing a wider skill set for an increasingly digitalised world. This chapter explores technologies such as 
social media, e- portfolios and recording simulations that augment students' experience, development and readiness for employability. Bolton and Emery look at how educational technology is used to simulate the workplace by capturing and reflecting on actions in real world situations, while recognising that using technology of the workplace can facilitate learning outcomes.

Chapter 16, 'Real Time, Real World Learning-Capitalising on Mobile Technology,' critiques an active learning approach that makes use of mobile technology and augmented reality to enhance students' real world learning. Students are now bringing a variety of mobile technology into the classroom, and Parry, Richards and McAuliffe discuss the challenge of maintaining students' interest and engagement when they can be connected to the world outside the classroom via electronic devices.

The book concludes with a presentation of the research in Chap. 17: 'Conclusion: Real World Learning-Researching and Co-constructing Working Definitions for Curriculum Development and Pedagogy, coconstructed with the book authors. Through the method of concept mapping, the authors discuss their views and experience of 'real world learning'. A thematic analysis of the author focus groups identifies three themes of fidelity, individuality and mutuality. A discussion of the themes applies the authors' experience of real world curriculum planning and pedagogy in higher education and the future implications that this may entail.

\section{References}

Atkins, M. J. (2009). Oven-ready and self-basting: Taking stock of employability skills. Teaching in Higher Education, 4(2), 267-280. https://doi. org/10.1080/1356251990040208

Billett, S. (2010). The perils of confusing lifelong learning and lifelong education. International Journal of Lifelong Education, 29(4), 401-413. https://doi. org/10.1080/02601370.2010.488803

Boss, S. (2015). Real-world projects: How do I design relevant and engaging learning experiences?. ASCD. 
Bridgstock, R. (2009). The graduate attributes we've overlooked: Enhancing graduate employability through career management skills. Studies in Higher Education, 28(1), 31-44. https://doi.org/10.1080/07294360802444347

Bridgstock, R., \& Cunningham, S. (2016). Creative labour and graduate outcomes: Implications for higher education and cultural policy. International Journal of Cultural Policy, 22(1), 10-26. https://doi.org/10.1080/1028663 2.2015.1101086

Ellstrom, P.-E. (2011). Informal learning at work: Conditions, processes and logics. In M. Malloch, L. Cairns, K. Evans, \& B. O'Connor (Eds.), The Sage handbook of workplace learning (pp. 105-119). London/California/New Delhi/Singapore: Sage.

European Commission. (2014). Educating and training monitor 2014. Retrieved from http://ec.europa.eu/education/library/publications/ monitor14_en.pdf

Finch, D., Falkenberg, L., McLaren, P. G., Rondeau, K. V., \& O'Reilly, N. (2018). The rigour-relevance gap in professional programmes: Bridging the 'unbridgeable' between higher education and practice. Industry and Higher Education, 32(3), 152-168. https://doi. org/10.1177/0950422218768205

Fuller, A., \& Unwin, L. (2003). Learning as apprentices in the contemporary UK workplace: Creating and managing expansive and restrictive participation. Journal of Education \& Work, 16(4), 407-426. https://doi. org/10.1080/1363908032000093012

Grey, M. (2018, December 27). Graduate outcomes: Necessity is the mother of invention. Wonkhe. Retrieved from https://wonkhe.com/blogs/ graduate-outcomes-necessity-is-the-mother-of-invention/

Heath, C., \& Heath, D. (2017). The power of moments: Why certain experiences have extraordinary impact. London/Toronto/Sydney/Auckland/Johannesburg: Bantam Press.

Herrington, J., Reeves, T. C., \& Oliver, R. (2010). A guide to authentic e-learning. New York: Routledge.

Holley, K. A. (2009). Understanding interdisciplinary challenges and opportunities in higher education. ASHE Higher Education Report, 35(2), 1-131.

Illeris, K. (2003). Towards a contemporary and comprehensive theory of learning. International Journal of Lifelong Learning, 22(4), 396-406. https://doi. org/10.1080/02601370304837

Jacoby, B. (2009). Civic engagement in higher education: Concepts and practices. John Wiley and Sons. 
Kernohan, D. (2018). Plenty ventured, but what was gained?. Retrieved from https://wonkhe.com/blogs/plenty-ventured-but-what-was-gained/

Kinchin, I., Heron, M., Hosein, A., Lygo-Baker, S., Medland, E., Morley, D. A., \& Winstone, N. E. (2018). Researcher-led academic development. International Journal for Academic Development, 23(4), 339-354. https://doi. org/10.1080/1360144X.2018.1520111

Laur, D. (2013). Authentic learning experiences: A real-world approach to projectbased learning: Routledge.

Lefebvre, H. (1992/2004). Rhythm analysis: Space, time and everyday life (Trans. S. Elden \& G. Moore). London: Continuum.

Lester, S., \& Costley, C. (2010). Work based learning at higher education level: Value, practice and critique. Studies in Higher Education, 35(5), 561-575. https://doi.org/10.1080/03075070903216635

Lucas, B., \& Guy, L. (2013). Expansive education: Teaching learners for the real world. McGraw-Hill Education.

Marris, P. (2018). The experience of higher education (Vol. 17). Routledge.

Mason, G., Williams, G., \& Cranmer, S. (2009). Employability skills initiatives in higher education: What effects do they have on graduate labour market outcomes. Education Economics, 17(1), 1-30. https://doi. org/10.1080/09645290802028315

Maxwell, M., Stobaugh, R., \& Tassell, J. L. (2015). Real-world learning framework for secondary schools: Digital tools and practical strategies for successful implementation. Solutions Tree.

Miles, E. W. (2017). Historical context and insights for criticisms of the 21 st century business school. Journal of Education for Business, 92(5), 245-254. https://doi.org/10.1080/08832323.2017.1335277

Moore, T. J. (2011). Critical thinking and disciplinary thinking: A continuing debate. Higher Education Research \& Development, 30(3), 261-274. https:// doi.org/10.1080/07294360.2010.501328

Morley, D. A. (2017). Degree apprenticeships are a ray of light in a gloomy sector. Retrieved from https://www.timeshighereducation.com/blog/degreeapprenticeships-are-ray-light-gloomy-sector

Morley, D. A., Archer, L., Burgess, M., Curran, D., Milligan, V., \& Williams, D. (2017). A panel discussion - The impact of the university student placement experience on both students and academics. Paper presented at the ExCiTes Teaching and Learning conference, 5 January 2017, University of Surrey, Guildford, UK. 
Nguyen, N. T., Tran, T. L., \& Le, T. T. T. (2019). Work-integrated learning for enhancing graduate employability: Moving from the periphery to the Centre of the curriculum. In Reforming Vietnamese higher education (pp. 113-132). Singapore: Springer.

Office for Students. (2019). NSS questionnaire 2019. Retrieved from https:// www.officeforstudents.org.uk/media/ceed008b-1 f02-48ad-b566d9ca7080376f/nss-2019-questionnaire.pdf

Pearson. (2019). The global learner survey. Retrieved from https://www.pearson. $\mathrm{com} /$ corporate/news/global-learner-survey.html

Rau, K., Griffith, R. L., \& Dieguez, T. A. (2019). Out of the classroom and into the deep end: Real world learning at ICCM. In M. A. Gonzalez-Perez, K. Linded, \& V. Taras (Eds.), The Palgrave handbook of learning and teaching international business and management (pp. 159-184). Palgrave Macmillan.

Remington-Doucette, S. M., Connell, K. Y. H., Armstrong, C. M., \& Musgrove, S. L. (2013). Assessing sustainability education in a transdisciplinary undergraduate course focused on real-world problem solving. International Journal of Sustainability in Higher Education, 14(4), 404-433. https://doi. org/10.1108/IJSHE-01-2012-0001

Schön, D. (1983). The reflective practitioner: How professionals think in action. Aldershot: Ashgate Publishing Limited.

Shah, H. (2018). Awarding university subjects gold medals is deeply flawed. The Guardian. Retrieved from https://www.theguardian.com/higher-educationnetwork/2018/jun/01/awarding-university-subjects-gold-medals-isdeeply-flawed

Sharma, S., Charity, I., Robson, A., \& Lillystone, S. (2018). How do students conceptualise a 'real world' learning environment: An empirical study of a financial trading room? The International Journal of Management Education, 16(3), 541-557. https://doi.org/10.1016/j.ijme.2017.09.001

Tomlinson, M. (2017). Introduction: Graduate employability in context: Charting a complex, contested and multi-faceted policy and research field. In M. Tomlinson \& L. Holmes (Eds.), Graduate employability in context (pp. 1-40). London: Palgrave Macmillan.

Trilling, B., \& Fadel, C. (2009). 21st century skills: Learning for life in our times. San Francisco: John Wiley and Sons.

Turner, G. (2011). Surrendering the space: Convergence culture, cultural studies and the curriculum. Cultural Studies, 25(4-5), 685-699. https://doi.org/1 $0.1080 / 09502386.2011 .600556$ 
Wenger, E. (1998). Communities of practice: Learning, meaning and identity. New York: Cambridge University Press.

Woodside, J. M. (2018). Real-world rigour: An integrative learning approach for industry and higher education. Industry and Higher Education, 32(5), 285-289. https://doi.org/10.1177/0950422218784535

Open Access This chapter is licensed under the terms of the Creative Commons Attribution 4.0 International License (http://creativecommons.org/licenses/ by/4.0/), which permits use, sharing, adaptation, distribution and reproduction in any medium or format, as long as you give appropriate credit to the original author(s) and the source, provide a link to the Creative Commons license and indicate if changes were made.

The images or other third party material in this chapter are included in the chapter's Creative Commons license, unless indicated otherwise in a credit line to the material. If material is not included in the chapter's Creative Commons license and your intended use is not permitted by statutory regulation or exceeds the permitted use, you will need to obtain permission directly from the copyright holder.

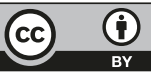

